\title{
Atrophic dermatofibroma*
}

\author{
Dermatofibroma atrófico
}

\author{
Amanda Nascimento C. de Macedo Mota ${ }^{1}$ \\ Daniel Lago Obadia ${ }^{2}$
}

\author{
Violeta Duarte Tortelly ${ }^{1}$ \\ Roberto Souto da Silva ${ }^{2}$
}

\begin{abstract}
Dermatofibroma is a benign fibrohistiocytic tumor, common and easily diagnosed when classical clinicopathologic features are present. The atrophic variant of dermatofibroma is of uncertain origin. This lesion is characterized clinically by a flat or atrophic and depressible surface. Histopathological features show reduction of the thickness of the dermis and elastic fibers. We report a typical case of this uncommon and probably underdiagnosed variant.

Keywords: Histiocytoma, benign fibrous; Histiocytoma, malignant fibrous; Skin diseases

Resumo: O dermatofibroma é um tumor fibrohistiocitário benigno, comum e facilmente diagnosticado quando apresenta os achados clinicopatológicos clássicos. O dermatofibroma atrófico é uma variante específica do dermatofibroma, de origem ainda incerta. Esta é caracterizada clinicamente por lesão plana ou atrófica, depressível à compressão. Ao exame histopatológico, observa-se redução da espessura da derme e redução das fibras elásticas. Relatamos um caso típico desta variante incomum e provavelmente subdiagnosticada.

Palavras-chave: Dermatopatias; Histiocitoma fibroso benigno; Histiocitoma fibroso maligno
\end{abstract}

\section{INTRODUCTION}

Dermatofibroma is a lesion often found in dermatological practice. It manifests as firm, hyperchromic and asymptomatic papules. Its most common location is the lower limbs. Compression of both sides presents the dimple sign, being the only pigmented lesion that is of diagnostic palpation relevance. The atrophic dermatofibroma is a variant of dermatofibroma, clinically characterized by an atrophic and depressed lesion. Histopathology reveals dermis thickness reduction by $50 \%$ in relation to the adjacent dermis. We report a typical case of atrophic dermatofibroma, an uncommon and probably underdiagnosed variant of a frequent lesion. Our aim was to be fully aware of this diagnosis when evaluating atrophic lesions.

Received on 29.10.2012.

Approved by the Advisory Board and accepted for publication on 20.12.2012

* Work performed at the Pedro Ernesto University Hospital, Rio de Janeiro State University (HUPE-UERJ), Rio de Janeiro (RJ), Brazil.

Conflict of interest: None

Financial funding: None

Dermatology Resident, Pedro Ernesto University Hospital - Rio de Janeiro State University (HUPE-UERJ), Rio de Janeiro (RJ), Brazil.

Dermatologist, Substitute Professor, Pedro Ernesto University Hospital, Rio de Janeiro State University (HUPE-UERJ), Rio de Janeiro (RJ), Brazil. 


\section{CASE REPORT}

Female, 57 years-old, had brown spots located on her left flank. Clinically well-defined, of firm consistency, atrophic surface measuring $3 \times 2 \mathrm{~cm}$, initially noticed about 10 years ago (Figure 1 ). She complained of mild itching in the area. She denied previous trauma or injection. On examination, a central depression was shown after compression of both sides of the lesion.

After excision of the lesion, the histopathological examination with hematoxylin and eosin revealed epidermal hyperplasia and, in the center of the lesion, a slight epidermal atrophy. In the dermis, there was a proliferation of spindle cells in storiform arrangement with central retraction of the dermis (Figure 2). Orceine staining revealed the absence of elastic fibers in the middle of the proliferation (Figure 3). The immunohistochemical evaluating was positive for XIIIa factor and negative for CD34, confirming the diagnosis of dermatofibroma in its atrophic variety (Figures 4 and 5).

\section{DISCUSSION}

Dermatofibromas are manifested clinically by firm, hyperchromic, asymptomatic, elevated or flat papules, measuring from a few millimeters to $1-2 \mathrm{~cm}$ in diameter and compressible on palpation. Single lesions are most commonly found, but it is not uncommon to find between two and five lesions in the same patient. The most often site involved is the lower limbs, particularly the legs. ${ }^{1}$ Women are more affected, in the proportion of 5:1, in the 20-50 years age range. ${ }^{2}$ Dermoscopy is an important tool in the evaluation of pigmented lesions and for defining diagnosis in typical cases. In dermatofibromas, there is a central plate and a fine, regular and pigmented network on the perifery, which classifies it as a non-melanocytic lesion.

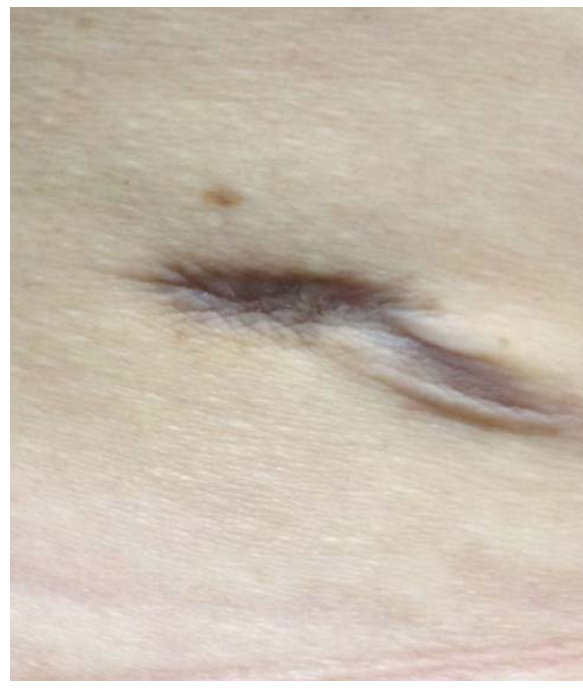

FIGURE 1:

Brownish, welldefined, itchy plaque adhereing to the subcutaneous, with atrophic surface. Central depression by compression of both sides

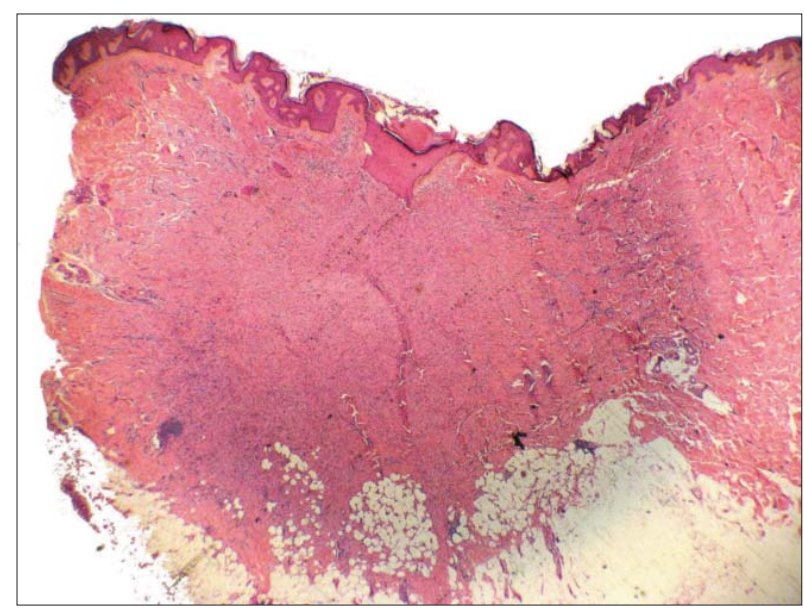

FIGURE 2: Epidermal hyperplasia with atrophy in the center of the lesion. Proliferation of spindle cells in storiform arrangement in the dermis and collagen sclerosis, determining central retraction

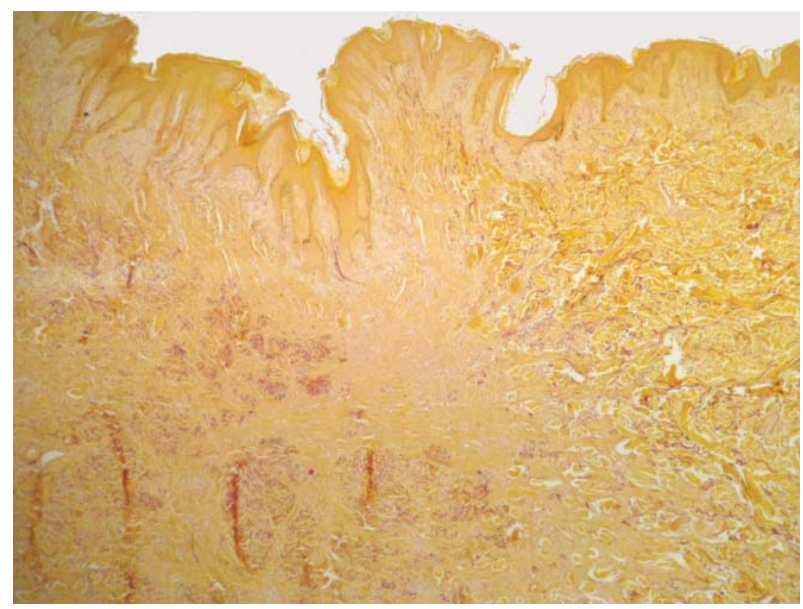

FIGURE 3: Orcein staining revealed absent of elastic fibers in the middle of the proliferation

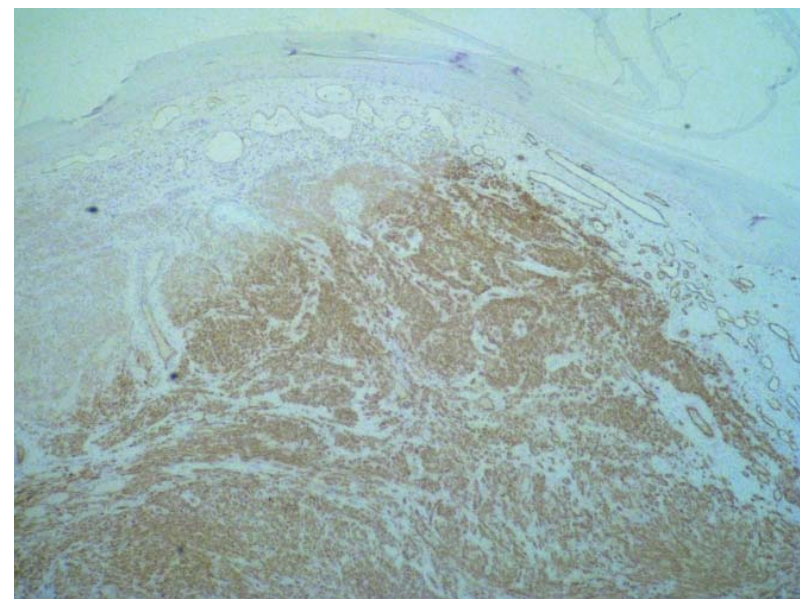

FIGURE 4: Immunohistochemistry analysis for CD34 evidenced negativity 


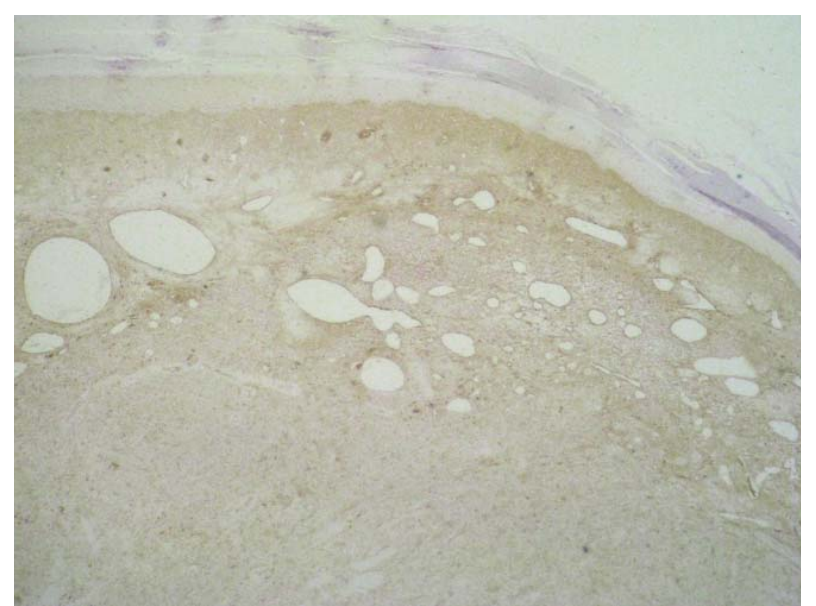

FIGURE 5: Immunohistochemistry analysis for factor XIIIa evidenced positivity

Dermatofibroma is a proliferation of spindle cells located in the dermis, composed of a variable mixture of fibroblasts, collagen, histiocytes and blood vessels. Several variants have been identified and more than one may be present in the same lesion. From the cytological viewpoint, most cells are spindle to oval-shaped, with vesicular nuclei, scant cytoplasm and prominent bit. Among the spindle cells there are single or clustered foamy cells or hemosiderin. There is often a predominantly lymphocytic inflammatory infiltrate of variable intensity. Another histopathological finding is the encapsulation of collagen bundles, making it hyaline in the periphery of the tumor. ${ }^{3}$

Dermatofibromas present some variants according to their clinical presentation. ${ }^{2}$ Atrophic dermatofibromas represent approximately $2 \%$ and are clinically presented as oval, flat or atrophic plates, which become depressed by manual compression.

\section{REFERENCES}

1. Lourival Lopes Filho L, de Oliveira de Avelar Alchorne A. Pre-operative evaluation of the visible and palpable diameters of dermatofibroma. Int $\mathrm{J}$ Dermatol. 2003:42:736-7.

2. Curcó N, Pagerols X, García M, Tarroch X, Vives P. Atrophic dermatofibroma accompanied by aneurysmatic characteristics. J Eur Acad Dermatol Venereol. 2006;20: 331-3.

3. Canelas MM, Cardoso JC, Andrade PF, Reis JP, Tellechea 0. Fibrous histiocytomas: histopathologic review of 95 cases. An Bras Dermatol. 2010;85:211-5.

4. Ohnishi T, Sasaki M, Nakai K, Watanabe S. Atrophic dermatofibroma. J Eur Acad Dermatol Venereol. 2004;18:580-3.

5. Page EH, Assaad DM. Atrophic dermatofibroma and dermatofibrosarcoma protuberans. J Am Acad Dermatol. 1987:17:947-50

6. Ackerman $A B$. Fibrosing dermatitis: dermatofibroma. Histologic diagnosis of inflammatory skin disease. 2nd ed. Baltimore: Williams \& Wilkins; 1997. p.73.

7. Kiyohara T, Kumakiri M, Kobayashi H, Ohkawara A, Lao LM. Atrophic dermatofibroma. Elastophagocytosis by the tumor cells. J Cutan Pathol. 2000;27:313-5.

8. Young CR 3rd, Albertini MJ. Atrophic dermatofibrosarcoma protuberans: case report, review, and proposed molecular mechanisms. J Am Acad Dermatol. 2003;49:761-4.
This variant occurs especially in the upper portion of the womens' trunks (a ratio of 10:1). The average age of onset is 49.7 years. ${ }^{2,4}$

Page and Assaad published the first case report of atrophic dermatofibroma in $1987 .{ }^{5}$ Ackerman reported in 1997 that dermatofibroma resulted from trauma, causing three stages of inflammatory response: granulation tissue, granulomatous inflammation and fibrosis, this latter being responsible for this variant. ${ }^{6}$ However, the etiology remains unclear. Subsequently, Kiyohara et al. reported a typical case of atrophic dermatofibroma which proved to be elastophagocytosis of the collagen fibers, a possible cause of this variant. ${ }^{7}$ In 2003, Capt proposed that inhibition of platelet-derived growth factor beta (PDGFB) receptor could be the cause of the atrophy, resulting in alteration of the composition of the stroma. $^{8}$

Histopathologically, this disorder presents as a reduction of at least $50 \%$ of the thickness of the dermis relative to the adjacent dermis ${ }^{7,9}$ Specific staining for elastic fibers, such as van Gieson or Orcein, reveals a reduction or abolition of these., ${ }^{4,7}$ Immunohistochemical examination reveals positivity for factor XIIIa and negative for CD34, the opposite of what is observed in dermatofibrosarcoma protuberans in its atrophic variety. The other findings are similar to those of typical dermatofibromas. . $^{2,10,11}$

Clinical differential diagnoses include atrophic dermatofibrosarcoma protuberans, anetodermia, atrophic scarring, sclerodermiform epitelioma, morphea, atrophodermia and localized lipoatrophy.,2,40,11 Given that atrophic dermatofibroma is a frequently misdiagnosed variant of a common tumor, we emphasize the importance of considering this diagnosis if atrophic or sclerotic lesions are seen, especially in the upper portion of the trunk of middle-aged women. ${ }^{4} \square$

9. Zelger BW, Ofner D, Zelger BG. Atrofic variants of dermatofibroma and dermatofibrosarcoma protuberans. Histopathology. 1995;26:519-27.

10. Wu JK, Malik MM, Egan CA. Atrophic dermatofibrosarcoma protuberans: an uncommon and misleading variant. Australas J Dermatol. 2004;45:175-7.

11. Fleury LFF Jr, Sanches Jr JA. Primary cutaneous sarcomas. An Bras Dermatol. 2006;81:207-21.

MAILING ADDRESS:

Amanda Nascimento Cavalleiro de Macedo Mota

Boulevard 28 de setembro, 77 - Vila Isabel

20551-030 - Rio de Janeiro, RJ

Brazil

E-mail:amanda_mota@hotmail.com

How to cite this article: Mota ANCM, Tortelly VD, Obadia DL, Silva RS. Atrophic dermatofibroma. An Bras Dermatol. 2013;88(5):793-5. 